\title{
State budget revenue optimization using the simplex method
}

(C) Foundation of International Studies, 2021

\author{
Inna Shkolnyk \\ Sumy State University, \\ Ukraine \\ y.shkolnyk@uabs.sumdu.edu.ua \\ ORCID 0000-0002-5359-0521
}

\section{Serhiy Kozmenko}

University of Social Science,

Lodz, Poland;

University of Customs and Finance,

Dnipro, Ukraine

kormenko.uabs@gmail.com

ORCID 0000-0001-7710-484

\section{Jana Drahosova}

Faculty of Economics and Business,

Pan-European University in Bratislava,

Slovakia

jana.drahosova@paneurouni.com

ORCID 0000-0003-0539-9500

\section{Olga Kozmenko}

University of Economics and Innovation in Lublin,

Poland;

Kharkiv National University of Economics,

Ukraine

o.v.kozmenko@gmail.com

ORCID 0000-0003-0088-593X

\section{Khaled Aldiwani}

University of Customs and Finance,

Dnipro, Ukraine;

Higher Institute of Science and Technology,

Libya

kaled762008@yahoo.com 
Abstract. State budget revenue generation is the result of the implementation of fiscal policy and the basis for effective government performance. Given that the approaches to generating state budget revenues vary significantly between different countries in terms of the structure of tax revenues and their ratio to non-tax revenues, there is no unified optimal ratio. The article focuses on the study of this issue in Ukraine. Since Ukraine is trying to bring its financial system and, in particular, public finance, as close as possible to the standards and norms of the European Union, it is interesting to model the optimal structure of budget revenues based on the analysis of state revenues in the EU countries. In the article authors suggest the ways to optimizes Ukraine's state budget revenues using the simplex method, which is based on the use of data on their 2007-2019 structure. The main guideline in determining the limits of their optimal volume is the practice of forming national revenues in $25 \mathrm{EU}$ countries over the same period. An additional justification for determining the optimal structure was the use of regression analysis, the results of which were applied to determine the nature and strength of the functional relationships between the income structure and the integral coefficient of structural changes in GDP. Half of the items turned out to have a direct impact, while the other half had a reverse impact on the GDP structure by type of economic activity. Comparison of the obtained optimal values of individual income items with their actual values made it possible to substantiate that the share of internal taxes on goods, services, property and business taxes, as well as an increase in rent payments, needs to be revised upward. In the future, this will require a revision of the regulatory framework for specified taxes and the mechanism for their administration.

Keywords: public finance, taxes, fiscal policy, index of structural changes, economic and mathematical modelling.

JEL Classification: H60, H61, H70, H71
Received:

August, 2020

1st Revision:

March, 2021

Accepted:

May, 2021

DOI:

$10.14254 / 2071$

$8330.2021 / 14-2 / 16$

\section{INTRODUCTION}

The generation of state budget revenues significantly differs across countries, which is due to the peculiarities of structuring the financial system, the place and role of public finance in economic development. The existing single economic space of the European Union did not become the basis for common approaches to the implementation of fiscal and budgetary policies of the member states, which determine the state of filling government budgets. At the same time, given Ukraine's course towards European integration, there is a significant need to bring Ukraine's fiscal and budgetary policies closer to EU standards. For Ukraine, as well as for EU countries, in the face of current challenges and a significant burden on state budgets due to increased health care costs, support for economic activity and vulnerable social groups under the influence of the pandemic, the issue of optimizing state budget revenues is extremely important and requires new methods of balancing the revenues. On the one hand, determining the optimal state budget revenue structure is directly related to the structure of the country's GDP by type of economic activity, since their ratio largely determines the structure of tax and non-tax revenues. Furthermore, the distribution of the expenditure item can stimulate or restrain activity in various areas in the future. Therefore, 
the purpose of this article is to determine the optimal structure of state budget revenues, taking into account the practice of forming state revenues in the EU.

\section{LITERATURE REVIEW}

The formation of state budget revenues and their optimal ratio has long been the focus of researchers and remains relevant not only for countries where public finance is in the process of reforming, but also for countries with stable financial relations, including in terms of budgetary policy. Among the publications in the sample, the most cited are Pommerehne and Schneider (1978), who investigated the problem of fiscal illusion. The authors propose to consider the systematic understatement of the fiscal burden and its impact on the revenue and expenditure side of the budget using the example of Switzerland. It is worth noting the work of Brennan and Buchanan (1978), which substantiates the importance of choosing the optimal set of tax instruments for generating state budget revenues. Usher's publication (1986) is highly cited. It explores the problems of tax evasion and their impact on the formation of rules in public finance, the value of such evasions for the state budget revenues.

There are many other most cited publications devoted to the formation of state budget revenues in different regions and different groups of countries: Schwarz (2008), who focused on the Arab countries of the Middle East, Kollias and Paleologou (2006), and Dincecco (2009), who studied fiscal policies in the EU countries, Fairfield (2015), who focused on the formation of state budget revenues in Latin America, and others.

Among all the authors who have studied this issue, there is a leader in terms of citation. Analysis of publications by Afonso and Jalles (2016) showed that the vast majority of them explore budget and fiscal policy, as well as their relationship with monetary policy, especially in the European Union. Another work by Afonso and Jalles (2016a), devoted to the study of the illusory sustainability of public finances in OECD countries, using cointegration analysis, found that in some countries - Austria, Canada, France, Germany, the Netherlands, Sweden, and the United Kingdom, there is no stable link between the structure of revenues and expenditures of state budgets in these countries. Another study of fiscal determinants of government bond revenue distribution and improved fiscal balance notes that the rise in spending on civil servants' salaries and social spending has a relatively negative impact manifested in some imbalances in both revenue and expenditure, which also affects the growth in yield spreads of government bonds themselves.

The formation of the revenue side of the state budget affects the level of economic growth in a country. So, Chugunov et al. (2020) analyzed the impact of national revenues on economic growth in Ukraine using correlation and regression analysis. The authors concluded that to ensure macroeconomic stability and accelerate economic growth in the face of change, it is advisable to increase the share of direct taxes in the structure of national revenues and introduce a rational and coherent tax policy with strategic goals of socioeconomic development. Turyanskyy et al. (2020) argued that structural crises in the Ukrainian economy force us to reconsider the forms and methods of the tax mechanism. In particular, they proved the existence of a directly proportional relationship between the growth of tax revenues to Ukraine's budget and changes in some macroeconomic indicators. Vyhovska et al. (2019) note that the formation and use of financial resources of the state largely determine its financial potential. This conclusion is based on the use of an integrated approach to calculate the state's financial potential. It is also noted that trends are developing in Ukraine, which generally correspond to the trends emerging in the European Union.

Khalil and Pandow (2020), based on the analysis of public finances of the Gulf Cooperation Council (GCC) member countries and the use of the co-integration rank test and the vector auto-regression method, prove the existence of a significant influence of the state budget revenues on the formation of the countries' GDP. 
Strilets et al. (2020), studying the impact of COVID-19 on the state's budgetary security, note the importance of improving fiscal policy, including in terms of stimulating economic activity in Ukraine. Shkolnyk et al. (2020) note the significant impact of public finance on a state's financial security using the example of Poland and Ukraine. Bikas and Bagdonaite (2020) emphasize that the problem of transparency of public finance and the related problem of tax evasion, in particular VAT, are gaining great importance for the Baltic States, which causes significant damage to the functioning of the public sector and the financing of public expenditures, since the budgetary significance of this tax is very large.

Shkolnyk et al. (2020), in their work on modeling the state of public finances, estimated the loss of government and local budget revenues depending on the transparency of public authorities using Multiple Indicator-Multiple Cause and Dynamic Multiple Indicator-Multiple Cause models.

Chornovol et al. (2020) argue that a good financial management system is a lever for leveling budget imbalances, and that it should be aimed at optimizing financial and budgetary instruments to prevent the growth of public debt and budget deficits in GDP. The authors also conclude that the governance mechanism in Ukraine is strict and restrictive. Serikova et al. (2018), using Kazakhstan as an example, investigate the features of the organizational model of tax revenue management and tax administration activities and determine the peculiarities of forming a partnership model of tax management within the framework of a promising innovative development model. Later, Serikova et al. (2020) applied a correlation model to determine the relationship between macroeconomic indicators and state budget revenue generation in the form of taxes. The authors also noted the importance of choosing a tax revenue forecasting method for budget planning.

Frolov et al. (2021) analyzed structural changes in public finance in Ukraine and constructed projected values of the gap between revenues and expenditures. In this case, the projected income gaps significantly exceed the projected expenditure gaps, which means more stability in the formation of revenues and a rather low predictability of expenses. Shvets (2020) noted the importance of adhering to the golden rule of public finance, as well as the positive impact of well-established public spending and effective public procurement on long-term economic growth. Chugunov and Nasibova (2021), after examining the data on the state budget of 17 eurozone countries, found a significant impact of state budget expenditures on social protection on the level of countries' socio-economic development.

The study of the state of local finance, including income generation, is an integral part of public finance research. Depending on the system of state and local finance, built at the national level, there is a greater influence in the formation of revenues through the use of taxes at the national and local levels. Romenska et al. (2020) draw attention to the importance of moving to medium-term budget planning in order to form a balanced budget, both in terms of revenue and expenditure. The authors argue that medium-term budget planning will contribute to transparent, efficient and high-quality use of budget funds with limited government potential to increase tax revenues. Dave (2020) examines the financial health of local governments in India's urban areas and notes that decentralization processes are important due to a multilayered governance system that stimulates the efficiency of both revenue and expenditure generation in local budgets and thus has a positive impact on the formation of public finance in general. Similar studies are being carried out in Ukraine.

In particular, Dekhtyar et al. (2020) have assessed the impact of decentralization on local finances and determined the dynamics of local budget execution in Ukraine in terms of revenues, expenditures and transfers, using an integrated index obtained through taxonomic analysis. Lysiak et al. (2020) note the importance of financial sustainability of local budgets and emphasize the need for its systematic evaluation. They also note that it is important for Ukraine to improve the quality of budget planning, since the flows of funds between state and local budgets are highly dependent. 
Melnyk et al. (2018) investigate the impact of financial decentralization on macroeconomic stability; the latter is defined as a functional relationship between macroeconomic stability and the degree of financial decentralization, described by indicators such as the level of money supply growth, investment and openness of the economy, and financial decentralization. At the same time, the degree of financial decentralization is determined in terms of revenue and expenditure decentralization. Okoye et al. (2019) note that given that in many countries, including Nigeria, the budget is unbalanced in revenues and expenditures, a budget deficit is formed. As a result of the application of the econometric autoregressive model with distributed lags, it is noted that public policy should be aimed at low inflation and higher exchange rates, as well as productive investment of oil revenues and economic diversification as a panacea for permanent use of budget deficit. Chugunov et al. (2019), based on the analysis of fiscal policy in developing countries, identified the role of fiscal policy in ensuring macroeconomic stability and social well-being, and identified vectors for further development in terms of generating revenue and expenditure components of the budget.

It should be noted that each country has its own specific taxation system, which is formed under the influence of many factors, which also affects budget revenue generation. Krasnov et al. (2020) analyze the harmonization of approaches to taxation and the formation of state revenues using the example of the Eurasian Economic Union. They conclude that there are significant differences in approaches to taxation and rates of basic budget-generating taxes and excises; in addition, there are non-tariff barriers in the markets for goods and services that impede mutual trade and access of excisable goods to the markets of the union states. Measures to improve taxation systems in order to increase budget revenues and ensure the competitiveness and financial stability of the EAEU member states should include the creation of a unified identification system for foreign trade operators (UISFTO), improvement of electronic services, automation of information exchange between tax and customs authorities, as well as the introduction of new tax administration mechanisms in digital trade. Abodher (2020) analyzes the influence of religious factors on tax payment in Libya. Omari and Khersiat (2020) noted that it is important for Jordan to apply national integrity standards that affect the government budget. In addition, based on the results of economic and mathematical modeling, they determined that for state budget generation, the transparency standard is the most important, and the rule of law is the least important.

Thus, this study analyzes the structure of Ukraine's state budget revenues using economic and mathematical modeling. It can be argued that optimizing the revenue side of the state budget and the related optimization in the field of fiscal policy is relevant for countries with different levels of economic development, becoming more and more important at the present stage.

\section{DATA AND METHODOLOGY}

In general, the classical optimization problem, which belongs to the group of structural economic and mathematical models, is to find the optimal (maximum or minimum) value of the objective function.

Unknown variables, which include the corresponding items ( $z 1-z 11)$ of Ukraine's budget in the form of shares of GDP (Appendix A), are calculated for the period from 2007 to 2019. The integral coefficient of GDP structural changes by type of activity acts as a dependent variable.

The research sequence is as follows: At the beginning of the development of the optimization model, the objective function is determined. This is the integral coefficient of structural changes in GDP by type of activity, as one of the state's economic stability indicators adjusted for the value of budget revenues by items.

The integral coefficient of structural changes was calculated as follows: First, the linear Kl (formula 1) and quadratic Ks (formula 2) coefficients of absolute structural changes were calculated, then the quadratic coefficient of relative structural changes Ksr (formula 3) and the integral coefficient $\mathrm{Kd}$ (formula 4): 


$$
K_{l}=\bar{\Delta} d_{i}-d_{0}=\frac{\sum_{i=1}^{k}\left|d_{i j}-d_{i j-1}\right|}{k}
$$

where $\Delta d_{i}$ is an indicator of the absolute increase in the specific weight of the $i$-th part of the total amount, $k$ is the number of components of the structure under study.

$$
\begin{aligned}
& K_{S}=\delta_{d_{i}-d_{0}}=\sqrt{\frac{\sum_{i=1}^{k}\left(d_{i j}-d_{i j-1}\right)^{2}}{k}} \\
& K_{s r}=\delta_{\frac{d_{i}}{d_{0}}}=\sqrt{\sum_{i=1}^{k} \frac{\left(d_{i j}-d_{i j-1}\right)^{2}}{d_{i j-1}} \cdot 100} \\
& K_{d}=\sqrt{\frac{\sum_{i=1}^{k}\left(d_{i j}-d_{i j-1}\right)^{2}}{\sum_{i=1}^{k} d^{2}{ }_{i j-1}+\sum_{i=1}^{k} d^{2}{ }^{2} j}}
\end{aligned}
$$

The values of the calculated coefficients are given in Appendix B.

The general form of the state budget revenue optimization model is as follows:

$$
F=\sum_{j=1}^{n} d_{j} z_{j} \rightarrow \max (\min )
$$

with the following restrictions:

$$
\begin{aligned}
& \sum_{j=1}^{n} a_{i j} z_{j} \leq b_{i}(i=1, \ldots k), \\
& \sum_{j=1}^{n} a_{i j} z_{j}=b_{i}(i=k+1, \ldots l), \\
& \sum_{j=1}^{n} a_{i j} z_{j} \geq b_{i}(i=l+1, \ldots m) \\
& z_{j} \geq 0
\end{aligned}
$$

where $a_{i j}, b_{i}$, and $d_{i j}$ are given constant values.

To determine the objective function parameters, multiple regression analysis is used, which reveals changes in the average level of an effective trait, depending on changes in the factorial trait. The objective function for optimizing the state budget revenue structure will be as follows:

$$
F_{r}=\alpha+d_{1} z_{1}+d_{2} z_{2}+\ldots+d_{\mathrm{i}} z_{\mathrm{i}}+\varepsilon \rightarrow \max .
$$

The next step is to evaluate the results of the regression analysis and identify the nature and strength of functional relationships between state budget revenue items and the integrated coefficient of structural changes in GDP by type of activity.

The integrated coefficient of structural changes in GDP by type of activity is used as a dependent variable, and eleven state revenue items are used as independent variables.

To optimize the structure of state revenues, a corridor of permissible changes for each revenue item has been regulated. In the context of the chosen vector of Ukraine's European integration, the main guideline in determining the limits of the optimal size of state revenues is the practice of distributing national revenues in the EU for the period 2007-2019, obtained using the data bank of the Organization for Economic Co-operation and Development and the International Monetary Fund. Given that the data on 
state revenues of the EU countries are presented in the form of panel data, the Stata 13.0 software product was used for their analysis.

\section{RESULTS}

Before applying the method of optimizing the structure of state budget revenues, the presence of a correlation between the absolute GDP value and the amount of state budget revenues was assessed. The value of the correlation coefficient between GDP and the total amount of state budget revenues is 0.9365 . In the context of income items, the following values of Pearson's correlation coefficients were obtained (Table 1).

Table 1

The values of Pearson's correlation coefficients

\begin{tabular}{|c|c|c|c|c|c|c|c|c|c|c|}
\hline Variable & $\mathbf{z 1}$ & $\mathbf{z 2}$ & $\mathbf{z 3}$ & $\mathbf{z 4}$ & $\mathbf{z 5}$ & $\mathbf{z 6}$ & $\mathbf{z 7}$ & $\mathbf{z 8}$ & $\mathbf{z 9}$ & $\mathbf{z 1 0}$ \\
\hline $\begin{array}{c}\text { Pearson } \\
\text { correlation } \\
\text { coefficient }\end{array}$ & 0.9259 & 0.7009 & 0.9316 & 0.5869 & -0.7242 & -0.3298 & 0.5032 & 0.4804 & -0.1775 & 0.1877 \\
\hline
\end{tabular}

Source: own calculation

Given that the main goal is to optimize the structure of expenditures, it was determined that the target function should not be an absolute value, but rather structural changes in both GDP and state budget revenues. Having studied the structure of Ukraine's GDP from 2010 to 2019, it turned out that it was heterogeneous, that is, the value of the coefficient of structural changes in GDP ranged from a minimum of 0.05 to a maximum of 0.39 , which indicates the presence of structural imbalances in GDP. The oscillatory nature of the integral coefficient is confirmed by its visual representation in the form of a linear graph (Figure 1), and the variation of the series is confirmed by a box plot (Figure 2).

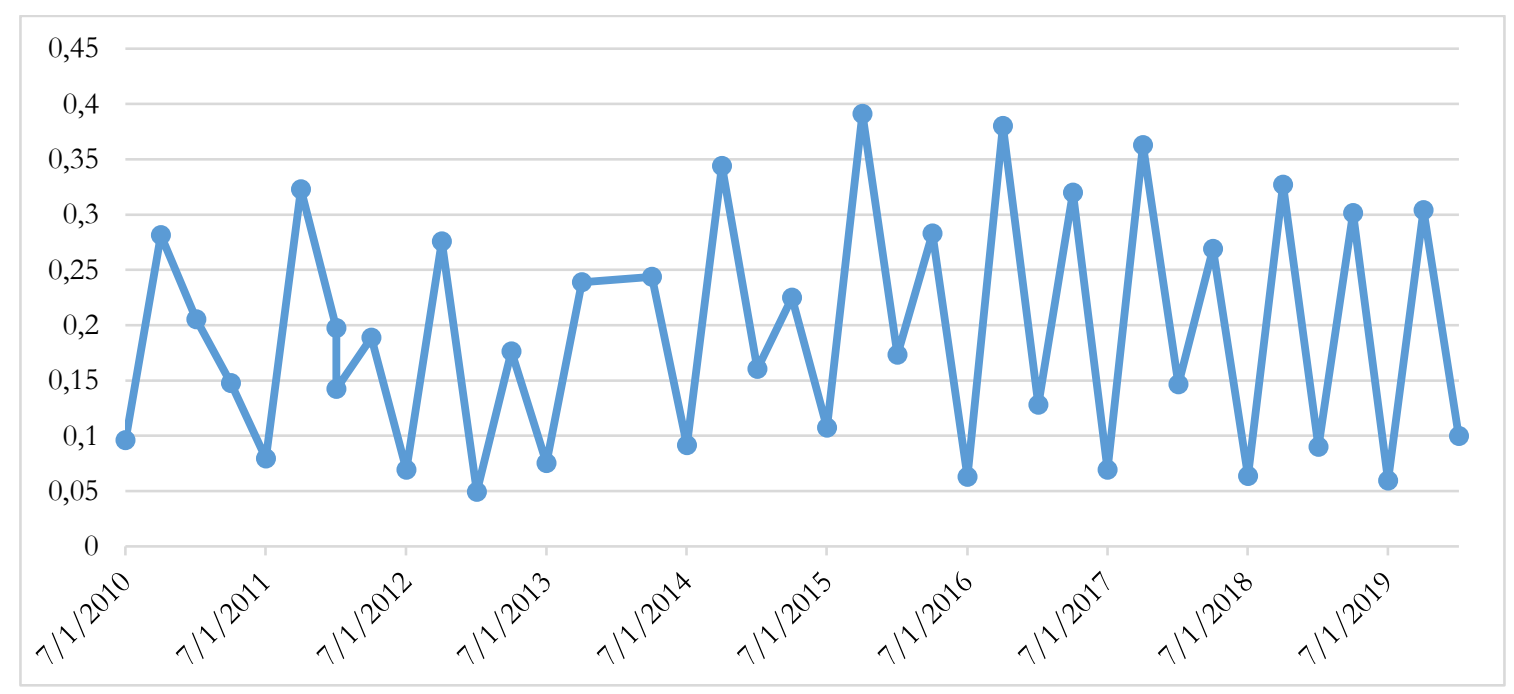

Figure 1. Trends in the integrated coefficient of structural changes in GDP by type of activity for 2010-2019

Source: own compilation 


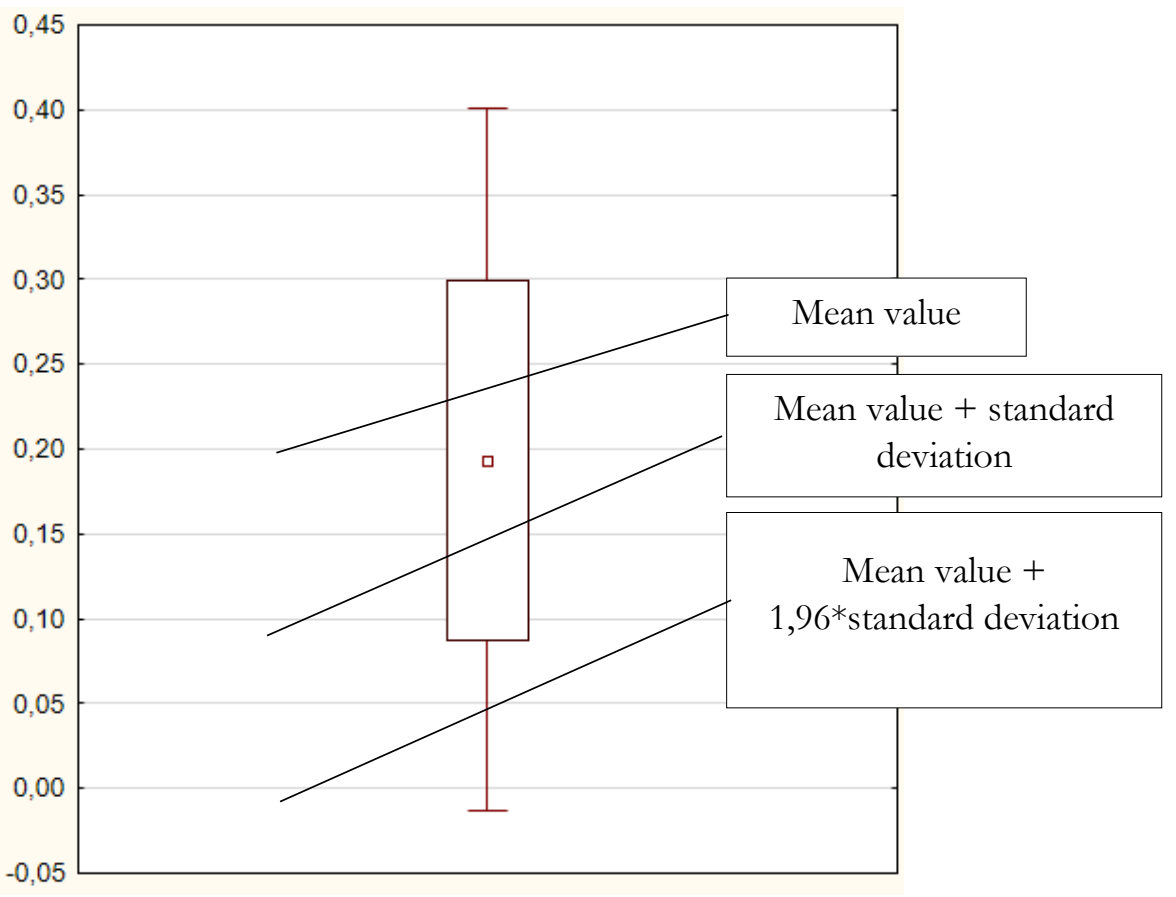

Figure 2. Box plot of the value of the integrated coefficient of structural changes in GDP by type of activity for 2010-2019

Source: own compilation

As a result of using the method of multiple linear regression, the following parameters of the equation were obtained:

$$
\begin{aligned}
F_{r}= & -0.324 z_{1}+0.283 z_{2}-1.135 z_{3}+0.140 z_{4}-0.146 z_{5}-0.108 z_{6}- \\
& -0.524 z_{7}+0.247 z_{8}+0.110 z_{9}-0.218 z_{10}+1.238 z_{11}
\end{aligned}
$$

Based on these results, it was assumed that there is a non-linear relationship between the analyzed variables. To eliminate nonlinearity, the data were logarithmized (Table 2).

After the data logarithmization, the regression results and the objective function are as follows:

$$
\begin{aligned}
F_{r}=- & 1.24 z_{1}+1.18 z_{2}-2.13 z_{3}+0.88-1.04 z_{5}-0.87 z_{6}- \\
& -1.73 z_{7}+1.1 z_{8}+0.91 z_{9}-1.05 z_{10}+2.31 z_{11} \rightarrow \max
\end{aligned}
$$

Taking into account the obtained regression coefficients, half of the items of state budget revenues have a direct effect on the integrated coefficient of structural changes in GDP by type of activity, but there are items that have an inverse effect. Let's analyze it in more detail.

Since state revenue items were used as independent variables as a share of GDP in $\%$, the interpretation of the results is as follows: The growth of each item by $1 \%$ causes a change in the dependent variable (the integral coefficient of structural changes in GDP) by the appropriate number of units.

Thus, due to an increase in the share of state revenues from fees and charges for the special use of natural resources, taxes on international trade and foreign transactions, other non-tax revenues, capital transactions and official transfers, the GDP structure will become less stable, which may lead to imbalances in the country's economic stability. Particular attention should be paid to the share of state revenues from official transfers and fees for the special use of natural resources, since the regression coefficient for these 
items is the highest among those that have a direct impact on the integrated coefficient of structural GDP changes by type of activity -2.31 and 1.18 , respectively.

Table 2

Regression analysis results to identify the relationship between state revenues and the integrated ratio of structural changes in GDP by type of activity

\begin{tabular}{|c|c|c|c|c|c|c|c|}
\hline Variable & $\begin{array}{c}\text { Regression equation } \\
\text { parameters }\end{array}$ & $\mathbf{R}^{2}$ & $\mathbf{R}$ & $\mathrm{F}^{*}$ & $\mathrm{t} * *$ & p-value & $\begin{array}{c}\text { Relationship } \\
\text { type }\end{array}$ \\
\hline $\mathrm{z}_{0}$ & 0.621 & \multirow{12}{*}{0.86} & \multirow{12}{*}{0.85} & \multirow{12}{*}{65.09} & 2.520 & 0.017 & \\
\hline $\mathrm{Z}_{1}$ & -1.24 & & & & -3.148 & 0.023 & $\downarrow$ Inverse \\
\hline $\mathrm{z}_{2}$ & 1.18 & & & & 2.547 & 0.031 & $\uparrow$ Direct \\
\hline$z_{3}$ & -2.13 & & & & -2.655 & 0.032 & $\downarrow$ Inverse \\
\hline $\mathrm{Z}_{4}$ & 0.88 & & & & 4.006 & 0.001 & $\uparrow$ Direct \\
\hline $\mathrm{Z}_{5}$ & -1.04 & & & & -3.241 & 0.017 & $\downarrow$ Inverse \\
\hline$z_{6}$ & -0.87 & & & & -3.803 & 0.025 & $\downarrow$ Inverse \\
\hline $\mathrm{z}_{7}$ & -1.73 & & & & -2.300 & 0.030 & $\downarrow$ Inverse \\
\hline$Z_{8}$ & 1.10 & & & & 2.981 & 0.015 & $\uparrow$ Direct \\
\hline Z9 & 0.91 & & & & 2.325 & 0.041 & $\uparrow$ Direct \\
\hline $\mathrm{Z}_{10}$ & -1.05 & & & & -4.029 & 0.006 & $\downarrow$ Inverse \\
\hline $\mathrm{Z}_{11}$ & 2.31 & & & & 2.331 & 0.025 & $\uparrow$ Direct \\
\hline
\end{tabular}

* The F-test value should exceed the table value (in this case, with $a=0.05$, it is 4.669 at the level of $p 0.007$ ), ** The t-test value should exceed the table value (in this case, with $a=0.05$, it is 1.7).

Source: own calculation

This imbalance can be corrected by increasing the share of state revenues from items that have an indirect impact on the dependent variable, namely, revenues from income taxes, profits and market value increases, domestic taxes on goods and services, rents, fees for fuel and energy resources, other taxes, property and business transactions and trust funds. In addition, revenues from domestic taxes on goods and services, as well as from property and business activities, mainly determine the pace of structural changes in GDP downward. The corresponding regression coefficients are 2.13 and 1.73 , respectively. Consequently, the state needs to increase both its own tax and non-tax revenues in order to avoid sharp structural changes in GDP.

After evaluating the main quality criteria of the constructed regression model (determination coefficient, Fisher's and Student's criterion), one can draw the following conclusions about the adequacy of the obtained modeling results:

- the value of t-statistics for some independent variables is greater than its tabular value (1.7) at a given level of significance, and p-level is less than 0.05, which indicates the statistical significance of the influence of the corresponding regressors on the dependent variable;

- the calculated value of the Fisher criterion of 65.09 is greater than the corresponding tabular value (4.669) at a given significance level, and p-level is less than 0.05 , which confirms the statistical significance of the entire regression equation;

- the determination coefficient R2 is 0.86, which indicates that a 50\% change in the integrated coefficient of structural changes in GDP by type of activity is due to changes in state revenues.

Thus, the obtained results of the constructed regression model can be assessed as adequate and correctly describing reality, and the regression coefficients can be used as parameters of the objective function to solve the optimization problem. 
To optimize state revenue items, it is necessary to regulate the corridor of permissible changes for each item separately.

As one can see, state revenue items such as revenues from taxes on income, profits and market value, domestic taxes on goods and services, property and business activities and trust funds have the highest range between the lower and upper "whiskers" in the box plot (minimum and maximum values). In addition, points that are outside the graph of variables z1, z7, z10 and z11, indicate the presence of outliers that do not fit into the inter-quarter ratio between the data in the presented series.

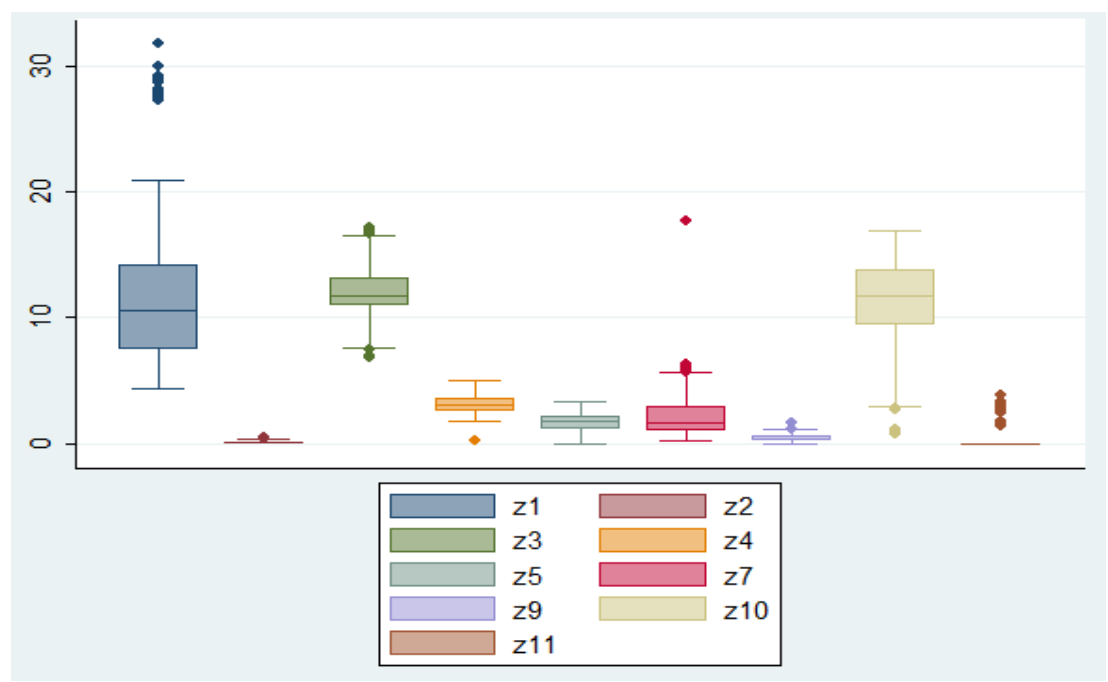

Figure 3. Box plot of the value of government revenue by item for the EU countries in 2007-2019 Source: own compilation

Despite the common financial market, economic differentiation between the EU countries remains noticeable. Figure 4 provides a more detailed picture of how the income tax burden is distributed across the EU.

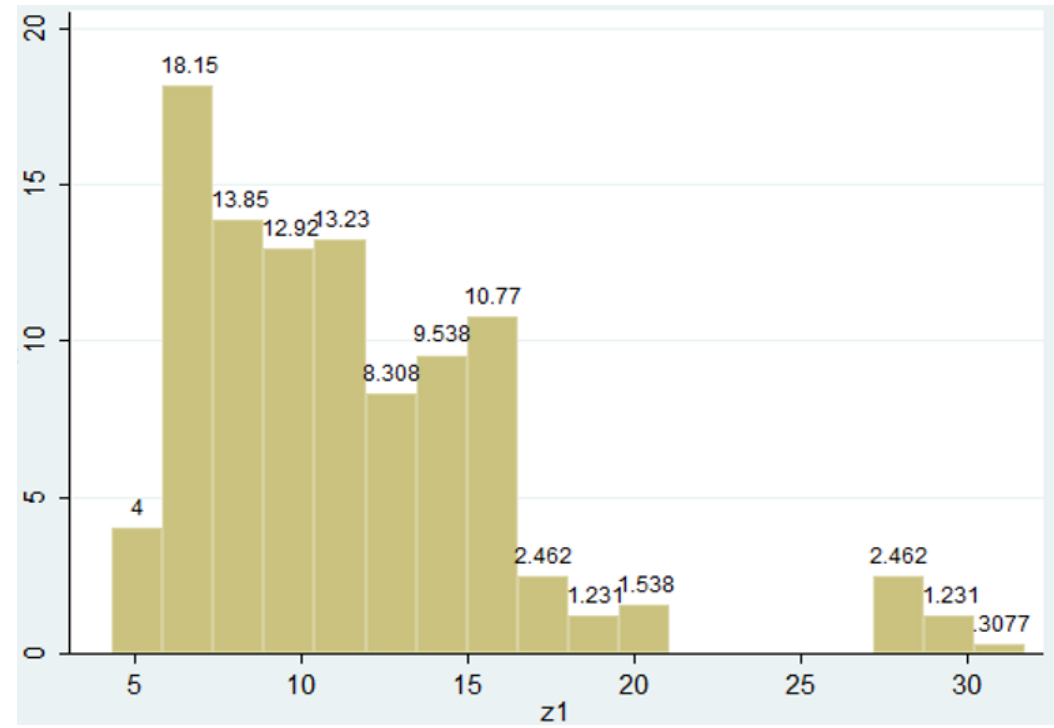

Figure 4. Distribution of EU countries by state revenues from taxes on income, profits and gains in market value in 2007-2019

Source: own compilation 
The share of state revenues in the structure of GDP for most EU countries fluctuates within 10\%, since about $50 \%$ of the studied values fall into this range. Denmark has the maximum values of expenditures (over 30\%), while Lithuania has the minimum values (less than $5 \%$ ).

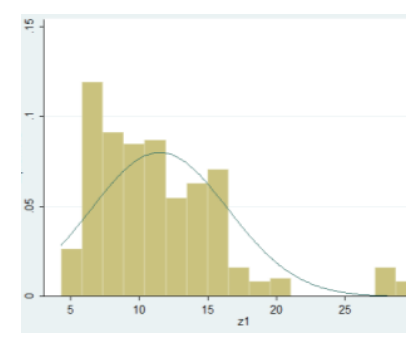

z1

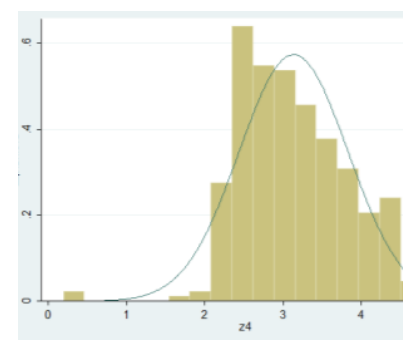

z4

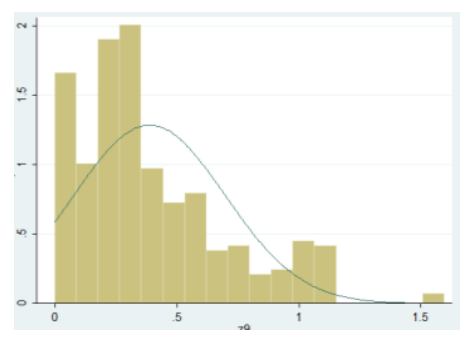

Z9

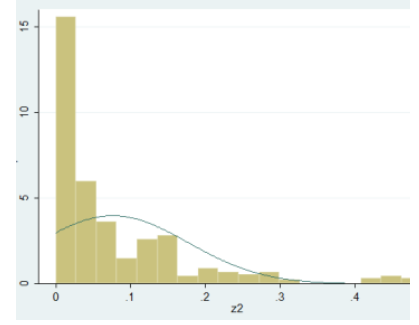

z2

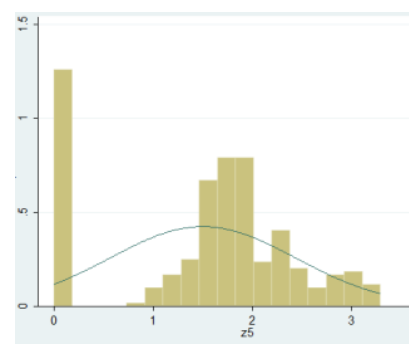

z5

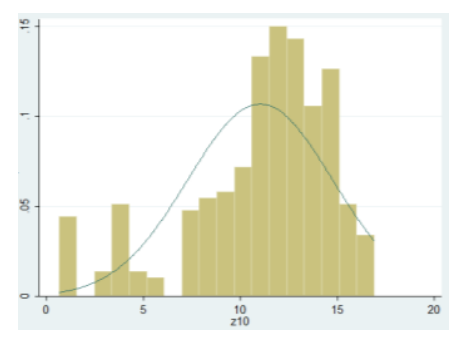

z10

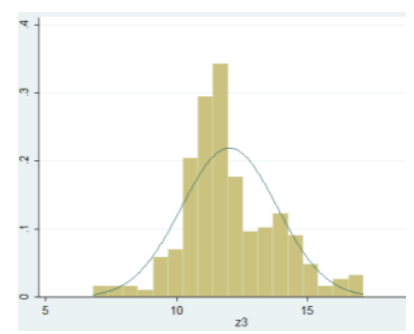

z3

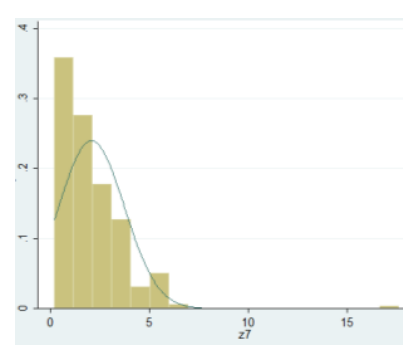

27

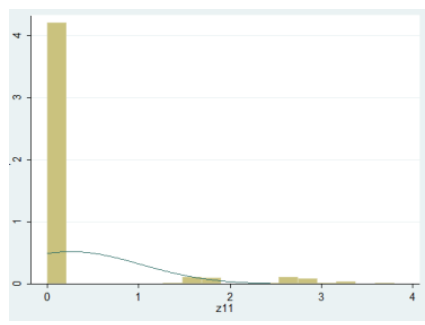

z11

Figure 5. Density of distributing state revenues in the EU by item in 2007-2019

Source: own compilation

As shown in Figure 5, the distribution of items of state revenues from domestic taxes on goods and services is visually closest to the normal distribution. It should be noted that the prerequisites for the correspondence of the distribution of some data series to the normal law include:

- equality of values of the mode (the value that is most often observed in the series) and the median ones (the value that is in the center of the series and divides it in half);

- equality of standard deviation (square root of the variance of the series) of the unit;

- equality of asymmetry (shift of the top of the graph to the left or right, depending on the value's sign) and excess (measure of the sharpness of the graph) to zero.

In addition, an important condition is the use of the arithmetic mean and the median to analyze the mean of the series. If the series is distributed according to the normal law, then the arithmetic mean is used, otherwise - the median.

A more detailed analysis of state revenues by item in the EU countries can be obtained using the main descriptive statistics presented in Table 3. 
Table 3

State revenue descriptive statistics in the EU in 2007-2019

\begin{tabular}{|c|c|c|c|c|c|c|c|c|}
\hline \multirow[b]{2}{*}{ Type of state revenues from } & \multicolumn{8}{|c|}{ Descriptive statistics } \\
\hline & 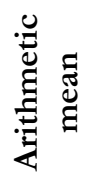 &  & $\frac{0}{\tilde{g}}$ & $\stackrel{\dot{\Xi}}{\dot{\Sigma}}$ & $\stackrel{\dot{x}}{\dot{\Sigma}}$ & 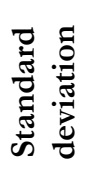 & 总 &  \\
\hline $\begin{array}{l}\text { Taxes on income, profit and an } \\
\text { increase in market value }\end{array}$ & 11.47 & 10.55 & - & 4.31 & 31.74 & 4.99 & 1.58 & 6.28 \\
\hline $\begin{array}{c}\text { Fees and charges for the special use } \\
\text { of natural resources }\end{array}$ & 0.08 & 0.03 & - & 0 & 0.49 & 0.1 & 2.0 & 7.37 \\
\hline Internal taxes on goods and services & 12.02 & 11.68 & - & 6.8 & 17.14 & 1.82 & 0.35 & 3.52 \\
\hline $\begin{array}{l}\text { International trade and foreign } \\
\text { transaction taxes }\end{array}$ & 3.13 & 3.05 & - & 0.19 & 5.04 & 0.7 & -0.03 & 3.87 \\
\hline $\begin{array}{l}\text { Rent, fees for fuel and energy } \\
\text { resources }\end{array}$ & 1.5 & 1.72 & - & 0.35 & 3.6 & 0.94 & -0.43 & 2.25 \\
\hline Property and business activities & 2.07 & 1.64 & - & 0.21 & 6.3 & 1.66 & 3.06 & 25.53 \\
\hline Capital transactions & 0.39 & 0.3 & - & 0 & 1.6 & 0.31 & 1.06 & 3.84 \\
\hline Trust funds & 11.02 & 11.76 & - & 0.68 & 16.91 & 3.73 & -1.08 & 3.72 \\
\hline Official transfers & 0.26 & 0 & - & 1.4 & 3.8 & 0.76 & 2.88 & 10.03 \\
\hline
\end{tabular}

Source: own calculation

An analysis of descriptive statistics refuted the assumptions regarding the normal distribution law of the above state revenue item, since the listed conditions are not fulfilled for any item: the values of the mode and the median are not equivalent, the standard deviation is not equal to one, and the skewness and kurtosis are nonzero, which indicates the asymmetry of all indicators. Therefore, to characterize the average level of state revenues and expenditures, the median must be used for the EU countries.

Table 4 presents descriptive statistics of Ukraine's state revenues.

Table 4

Ukraine's state revenue descriptive statistics for 2010-2019

\begin{tabular}{|c|c|c|c|c|c|c|c|c|}
\hline \multirow[b]{2}{*}{ Type of state revenues from } & \multicolumn{8}{|c|}{ Descriptive statistics } \\
\hline & 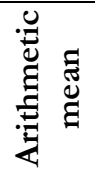 & 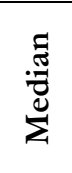 & 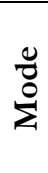 & $\dot{\Sigma}$ & 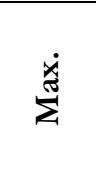 &  & 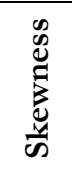 & 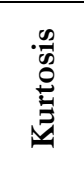 \\
\hline $\begin{array}{l}\text { Taxes on income, profit and an } \\
\text { increase in market value }\end{array}$ & 2.86 & 2.71 & - & 1.38 & 4.54 & 0.85 & 0.29 & -0.75 \\
\hline $\begin{array}{c}\text { Fees and charges for the special use } \\
\text { of natural resources }\end{array}$ & 0.44 & 0.20 & - & 0.10 & 1.71 & 0.42 & 1.56 & 1.96 \\
\hline Internal taxes on goods and services & 7.81 & 7.80 & - & 4.18 & 11.39 & 1.66 & 0.06 & -0.66 \\
\hline $\begin{array}{l}\text { International trade and foreign } \\
\text { transaction taxes }\end{array}$ & 0.70 & 0.64 & - & 0.40 & 1.26 & 0.24 & 0.89 & -0.11 \\
\hline $\begin{array}{l}\text { Rent, fees for fuel and energy } \\
\text { resources }\end{array}$ & 0.30 & 0.08 & - & 0.00 & 1.70 & 0.48 & 1.79 & 2.12 \\
\hline Property and business activities & 1.43 & 1.41 & - & 0.12 & 3.73 & 0.79 & 0.63 & 0.74 \\
\hline Capital transactions & 0.06 & 0.02 & - & 0.00 & 0.29 & 0.07 & 1.79 & 2.79 \\
\hline Trust funds & 0.04 & 0.02 & - & 0.00 & 0.11 & 0.04 & 0.98 & -0.24 \\
\hline Official transfers & 0.26 & 0.14 & - & 0.05 & 0.69 & 0.21 & 0.64 & -1.22 \\
\hline
\end{tabular}

Source: own calculation 
Given the values of the mode and the median, which are not equivalent, the standard deviation, which is different from one, as well as the skewness and kurtosis, which are not equal to zero, the median is also used to analyze the average level of state revenues in Ukraine. The average level of state revenues as a share of GDP by item for the EU countries is presented in Figure 6.

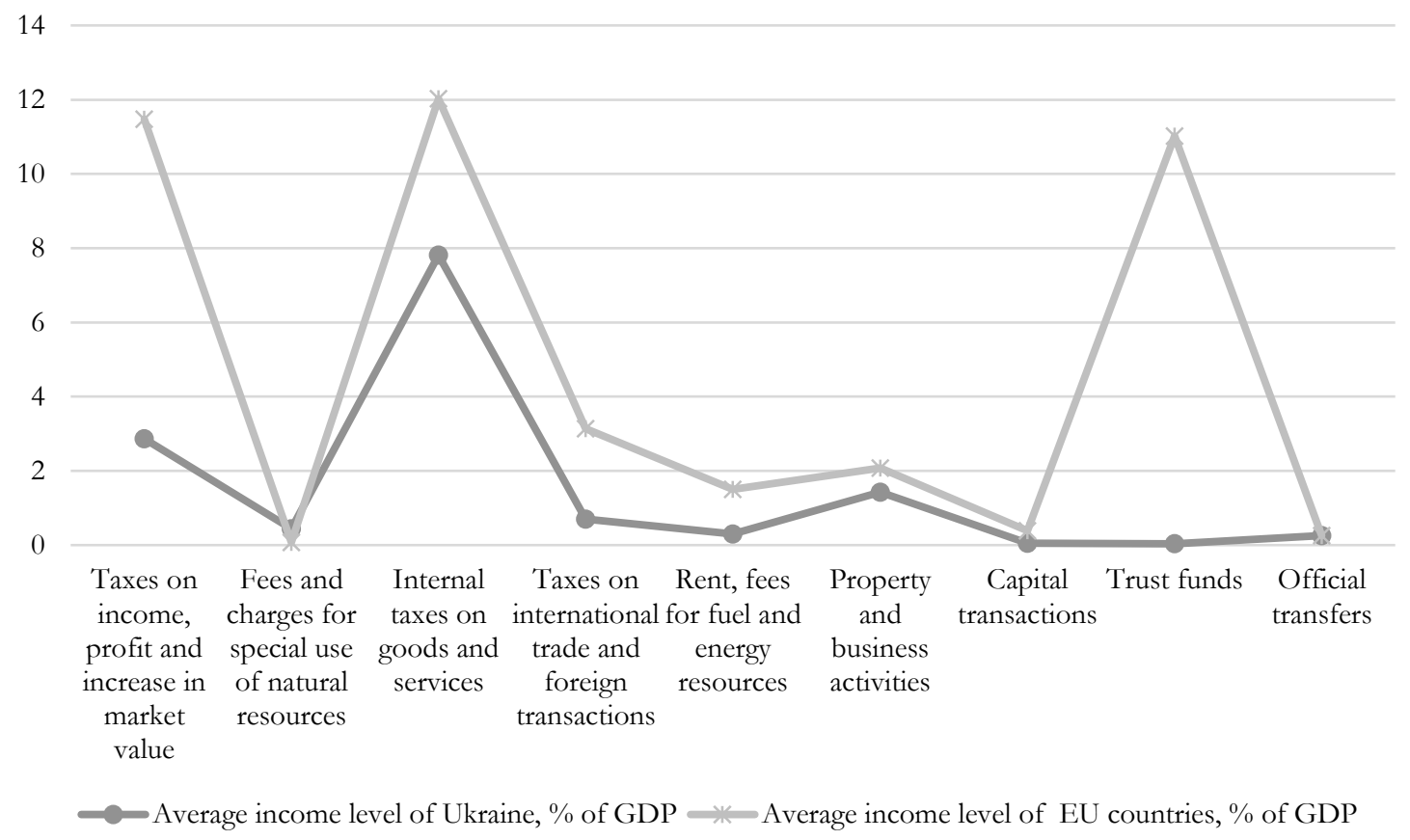

Figure 6. Average level of state revenues as a share of GDP for the EU countries and Ukraine in 2010-2018

Source: own compilation

The share of all state revenues in the structure of GDP in the EU countries is higher than in Ukraine. Exceptions include two items: revenues from fees and charges for the special use of natural resources and official transfers.

To build an economic and mathematical optimization model, it is necessary to determine the threshold values for each item of government revenues separately. According to government statistics of twenty-five EU countries on tax and non-tax revenues, the minimum and maximum amounts of state revenues were used as a share of GDP in 2007-2019 when determining the threshold values for each revenue item of the optimal amount of state revenues.

It should be noted that values other than European ones were used to set the limit for two revenue items. Exceptions included taxes on income, profit and gains in market value, as well as international trade and foreign transaction taxes. In Ukraine, the average level of revenue from income taxes, profits and increase in market value for 2010-2019 amounted to 2.86\% of GDP, while in 2019 this value ranged from $2.4 \%$ to $3.33 \%$. Analyzing the value of state revenues in comparison with a similar tax in the EU countries, it was found that the lowest level (4.3\% of GDP) was in Lithuania, and the highest (31.7\% of GDP) was in Denmark. As you can see, the amount of revenues from income taxes, profits and increases in market value in the EU countries fluctuates around 25\%. That is why it is incorrect to take them as limit values to solve optimal problems in Ukraine. Therefore, the comparative base for this income item was taken from the data of the Baltic countries, whose level of economic development is close to that of Ukraine. 
A similar situation is observed with the item of international trade and foreign transaction income taxes. In Ukraine, the average level of income under this item for the reviewed period was $0.7 \%$ of GDP, while in 2019 it almost halved compared to the previous period. Analyzing the extreme values of state revenues from international activities, one can see that the minimum value of income is in Greece $(0.2 \%$ of GDP), and the maximum value is in Estonia (5\% of GDP). Based on these data, the threshold values for revenue from international trade and foreign transaction taxes in Ukraine will be determined at a level not lower than the national average and not higher than in the Baltic States.

When building the second optimization model, the following restrictions were used:

$$
\begin{aligned}
& 4.31 \leq z_{1} \leq 7.0, \\
& 0.01 \leq z_{2} \leq 0.49, \\
& 6.8 \leq z_{3} \leq 17.1, \\
& 2 \leq z_{4} \leq 4.5, \\
& 0.35 \leq z_{5} \leq 3.6, \\
& 0.206 \leq z_{7} \leq 6.3, \\
& 0.0001 \leq z_{9} \leq 1.598, \\
& 0.681 \leq z_{10} \leq 16.912, \\
& 1.4 \leq z_{11} \leq 3.8 .
\end{aligned}
$$

Since Ukraine's structure of state revenues differs from the structure of the EU countries, the thresholds for items related to other tax and non-tax revenues will be regulated differently. Let's analyze the relationship between tax and non-tax government revenues of EU countries. Having found the maximum and minimum possible tax and non-tax revenues as a share of GDP for the EU countries, the following ratios are obtained (Figure 7 and 8).

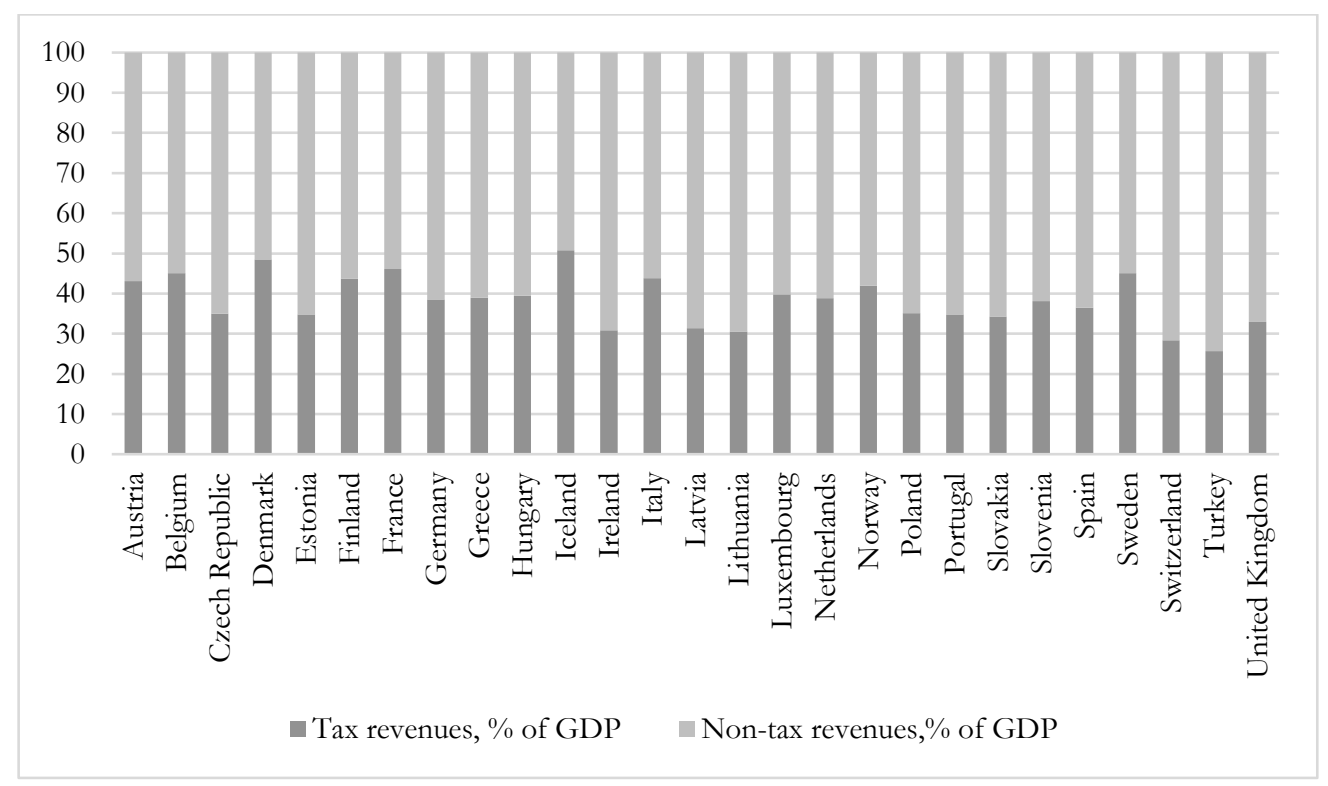

Figure 7. The ratio of the maximum values of tax and non-tax state revenues in the EU in 20072018

Source: own compilation 


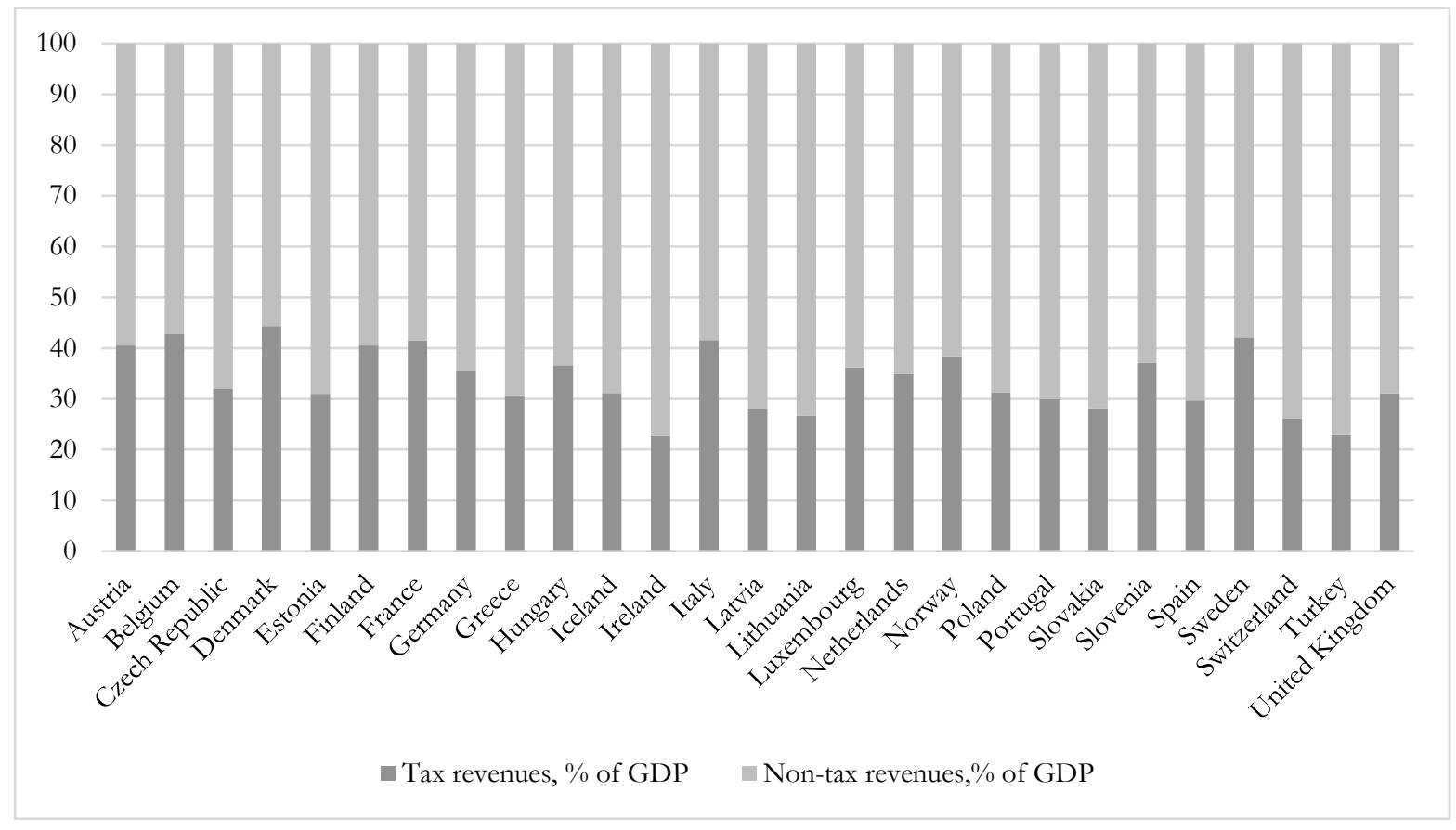

Figure 8. The ratio of the minimum values of tax and non-tax state revenues in the EU in 20072018

Source: own compilation

The difference in the ratio of tax and non-tax revenues of the EU countries is about $6 \%$ - from $44.35 \%$ to $50.81 \%$ for tax revenues and from $49.19 \%$ to $55.65 \%$ for non-tax revenues. Thus, two constraints are added to the optimization model:

$$
\begin{aligned}
& 44.35 \leq z_{1}+z_{2}+z_{3}+z_{4}+z_{5}+z_{6} \leq 50.81,(21) \\
& 49.19 \leq z_{7}+z_{8}+z_{9}+z_{10}+z_{11} \leq 55.65
\end{aligned}
$$

Threshold values for the objective function remain unchanged relative to the optimization model built for state spending:

$$
0 \leq F_{r} \leq 0.2 \text {. }
$$

As a result of taking into account all the necessary constraints and using the available integrated coefficient of structural changes in Ukraine's GDP by type of activity, the optimal distribution of state budget revenues of Ukraine as a share of GDP is as follows (Figure 9).

Comparison of the results obtained with a determined optimal value of national revenues with the existing average level confirmed the need to revise the structure. 


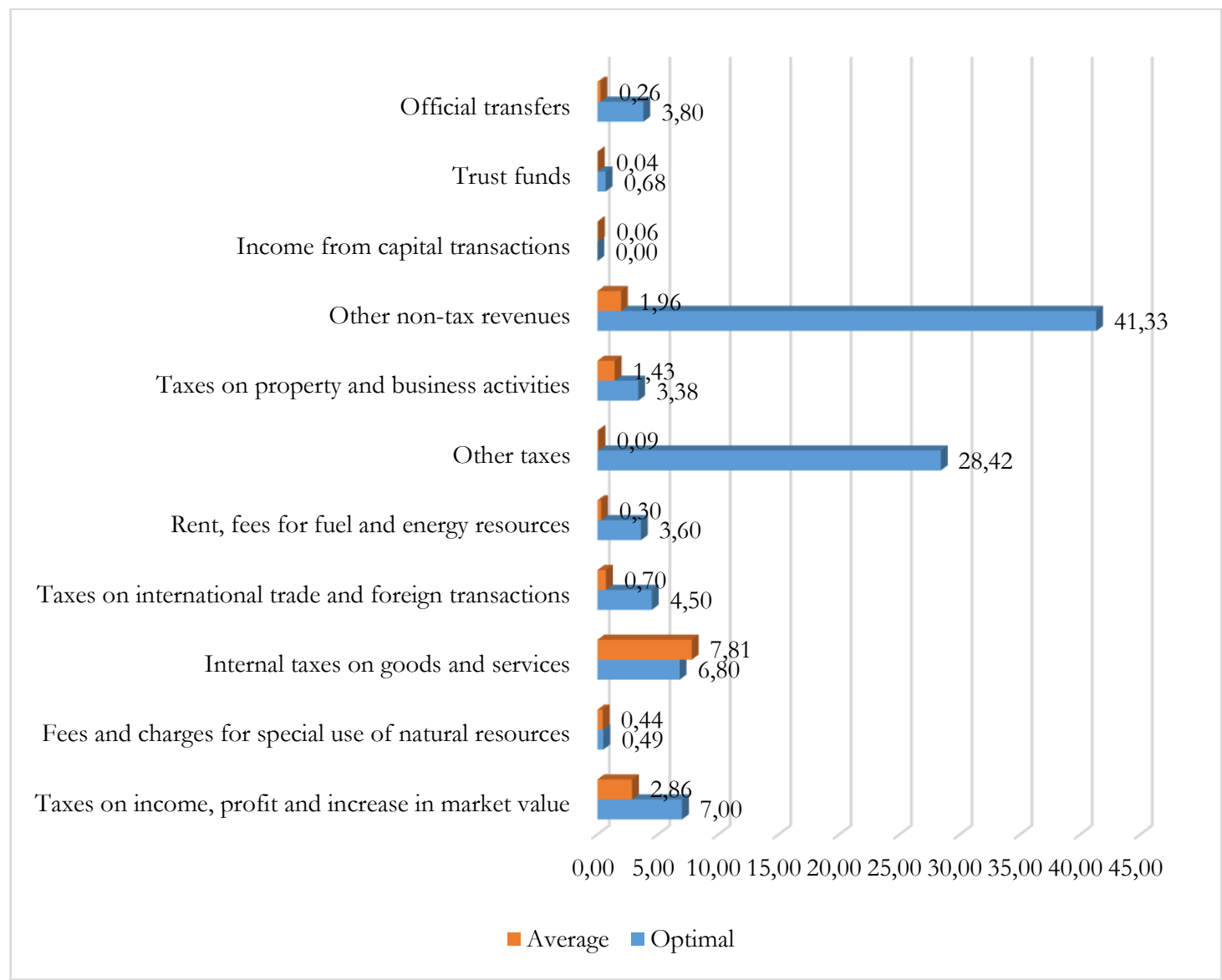

Figure 9. Comparison of the obtained optimal and existing average levels of state budget revenue distribution in Ukraine, \% of GDP

Source: own calculation

The share of fees and charges for the special use of natural resources, the amount of internal taxes on goods and services, as well as income from capital transactions, requires minimal changes in the volume of state revenues compared to the average level. The first item requires an increase of $0.05 \%$, the second - a decrease of $1.01 \%$, and the third requires a decrease of $0.06 \%$.

State revenue items such as taxes on income, profits and increases in market value, internal taxes on goods and services, and income from capital transactions, given their optimal values, need to be increased less than tenfold. The increase in the remaining budget revenue items to achieve the optimal value is critical and ranges from twelve for rent, fuel and energy fees to three hundred for other tax revenues. The direction and rate of changes in national revenues by item are presented in Table 5.

Taking as a basis for comparison with the obtained optimal value not the average level of state revenues, but its value as of January 1,2020, one can see that the gap between the values is somewhat narrowing (Figure 9). 
Table 5

Direction and rate of changes in national revenues, \% of GDP

\begin{tabular}{|c|c|c|c|c|}
\hline Item & $\begin{array}{c}\text { Average } \\
\text { value for } \\
\mathbf{2 0 1 0 - 2 0 2 0}\end{array}$ & $\begin{array}{c}\text { Optimal } \\
\text { value }\end{array}$ & Growth rate & $\begin{array}{c}\text { Direction of } \\
\text { change }\end{array}$ \\
\hline $\begin{array}{c}\text { Taxes on income, profit and increase in } \\
\text { market value }\end{array}$ & 7.00 & 2.86 & 2.44 & $\uparrow$ \\
\hline $\begin{array}{c}\text { Fees and charges for the special use of } \\
\text { natural resources }\end{array}$ & 0.49 & 0.44 & 1.11 & $\leftrightarrow$ \\
\hline Internal taxes on goods and services & 6.80 & 7.81 & 0.87 & $\uparrow$ \\
\hline $\begin{array}{c}\text { International trade and foreign transaction } \\
\text { taxes }\end{array}$ & 4.50 & 0.70 & 6.39 & $\uparrow$ \\
\hline Rent, fees for fuel and energy resources & 3.60 & 0.30 & 12.06 & $\uparrow$ \\
\hline Other taxes & 28.42 & 0.09 & 308.54 & $\uparrow$ \\
\hline Taxes on property and business activities & 3.38 & 1.43 & 2.36 & $\uparrow$ \\
\hline Other non-tax revenues & 41.33 & 1.96 & 21.13 & $\uparrow$ \\
\hline Income from capital transactions & 0.00 & 0.06 & 0.00 & \\
\hline Trust funds & 0.68 & 0.04 & 19.26 & $\uparrow$ \\
\hline Official transfers & 3.80 & 0.26 & 14.72 & $\uparrow$ \\
\hline
\end{tabular}

Source: own calculation

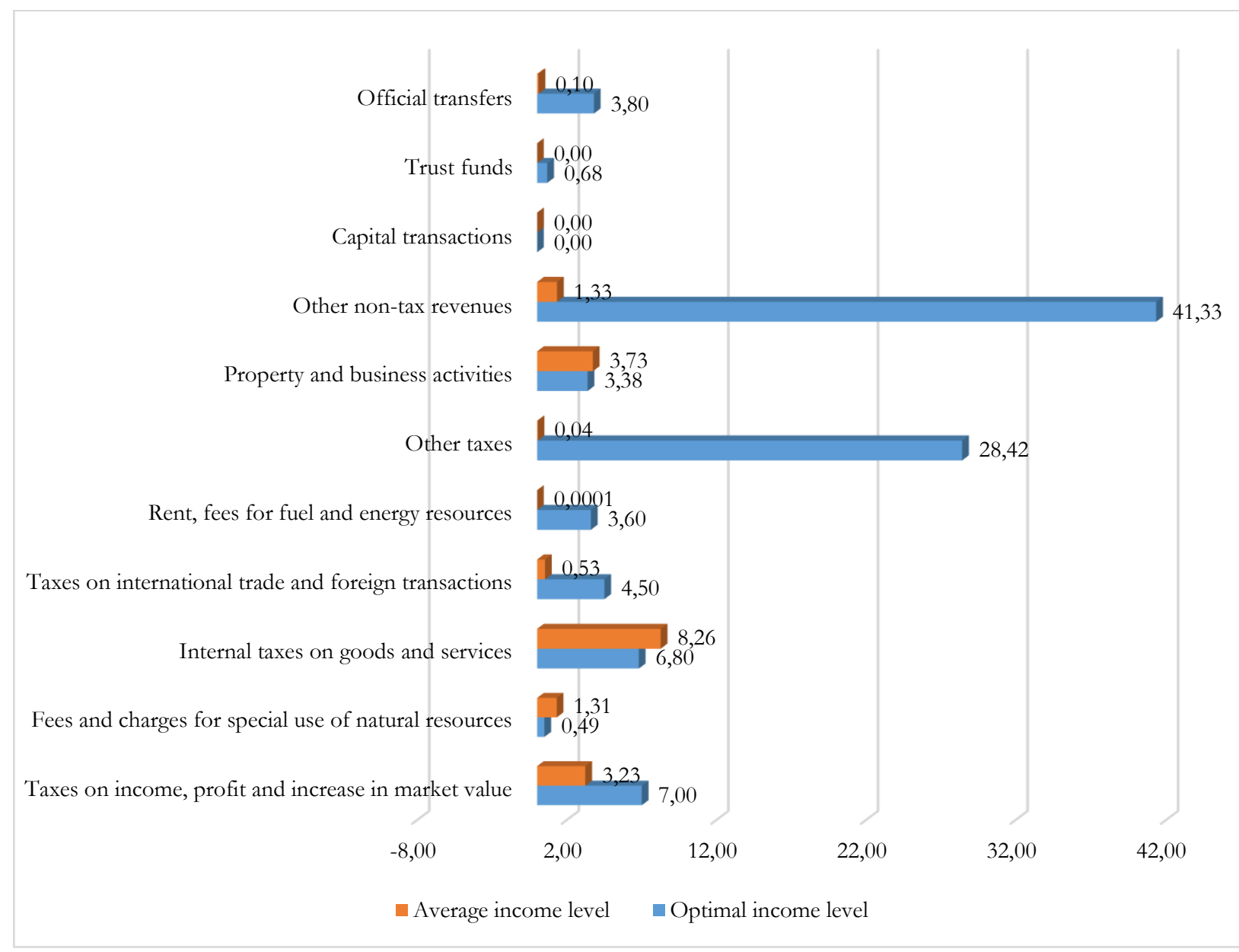

Figure 9. Comparison of the obtained optimal value and state budget revenues of Ukraine as of January 1, 2020, \% of GDP

Source: own calculation 
With such a redistribution of Ukraine's budget revenue items, there is a shift in the ratio of tax and non-tax revenues towards establishing a balance between them (Figure 10). The ratio obtained using the optimization model corresponds in absolute terms to Iceland, a highly developed country whose economy is built on Scandinavian principles - a symbiosis of capitalist development and a free market with a strong social security system. This result correlates with the determined optimal values of government expenditure items aimed at supporting economic activities of economic entities and social protection, which has a positive impact on the sustainability of the country's GDP structure.

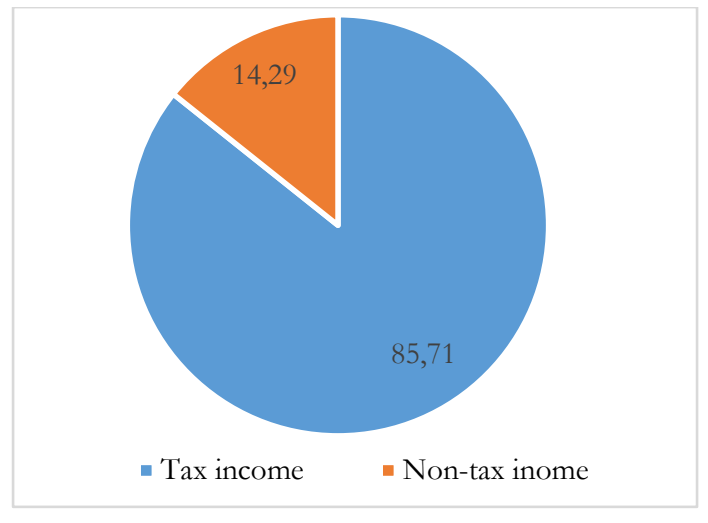

a)

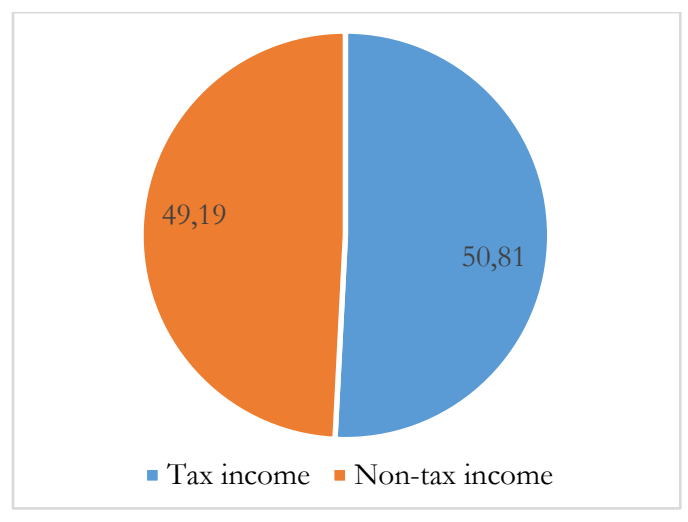

b)

Figure 10. The ratio of tax and non-tax revenues to Ukraine's state budget ( $a$ - as of January 1, 2020, b-obtained on the basis of the optimization model) Source: own calculation

Since the EU countries were chosen as a benchmark for the generation of state revenues, the results of the optimal model in terms of specific countries were analyzed. Thus, the optimal level of taxes on income, profits and increases in market value corresponds to the corresponding values of Slovakia (7.1\%), Greece $(7,1 \%)$ and Estonia (7.7\%); fees and charges for the special use of natural resources - the Netherlands; domestic taxes on goods and services, income from property and business activities, and official transfers - Spain; international trade and foreign transaction taxes - Poland; rent, fees for fuel and energy resources - Serbia; income from capital transactions - Slovakia; trust funds - Denmark.

\section{CONCLUSION}

The use of the simplex method for performing linear tasks made it possible to optimize the revenue and expenditure sides of Ukraine's state budget. To build an optimization model, it was necessary to calculate the integrated indicator of structural changes in Ukraine's GDP, which is taken as a dependent variable of the model. Its quarterly value calculated for the period 2010-2019 was heterogeneous and fluctuated from a minimum level of 0,05 to a maximum of 0.39 , which indicates the presence of a structural imbalance in GDP. To optimize government revenues, 11 variables were used, representing the main items of the revenue side. To determine the parameters of the objective function, multiple regression analysis was also used, which revealed a change in the average level of an effective trait, depending on changes in the factorial trait. Given the obtained regression coefficients, most of state budget revenue items have a direct effect on the integrated coefficient of structural changes in GDP by type of activity, but there are items that have an inverse effect. The limit values for each item of revenues were regulated by analyzing the relationship 
between tax and non-tax revenues in the EU countries. As a result, the optimal forecast values of individual revenue items of Ukraine's state budget were obtained.

\section{REFERENCES}

Abodher, F. M., Ariffin, Z. Z., \& Saad, N. (2020). Religious factors on tax non-compliance: evidence from Libyan selfemployed. Problems and Perspectives in Management, 18(1), 278-288. https://doi.org/10.21511/ppm.18(1).2020.24

Afonso, A., \& Jalles, J. T. (2016) Budgetary decomposition and yield spreads. Applied Economics Letters, 23(15), 10931098. https://doi.org/10.1080/13504851.2015.1136390

Afonso, A., \& Jalles, J. T. (2016a). The elusive character of fiscal sustainability. Applied Economics, 48(28), 2651-2664. https://doi.org/10.1080/00036846.2015.1128074

Bikas, E., \& Bagdonaite, G. (2020). Tax avoidance: The aspect of value added tax. Entrepreneurship and Sustainability Issues, 8(2), 590-605. https://doi.org/10.9770/jesi.2020.8.2(36)

Brennan, G., \& Buchanan, J. M. (1978). Tax instruments as constraints on the disposition of public revenues. Journal of Public Economics, 9(3), 301-318. https://doi.org/10.1016/0047-2727(78)90013-0

Chornovol, A., Tabenska, J., Tomniuk, T., \& Prostebi, L. (2020). Public finance management system in modern conditions. Investment Management and Financial Innovations, 17(4), 402-410. https://doi.org/10.21511/imfi.17(4).2020.34

Chugunov, I. \& Nasibova, O. (2021). Public funding of social protection: Impact on social indicators in Eurozone countries. Investment Management and Financial Innovations, 18(2), 181-192. doi:10.21511/imfi.18(2).2021.15

Chugunov, I., Makohon, V., Vatulov, A., \& Markuts, Y. (2020). General government revenue in the system of fiscal regulation. Investment Management and Financial Innovations, 17(1), 134-142. https://doi.org/10.21511/imfi.17(1).2020.12

Chugunov, I., Makohon, V., \& Markuts, Y. (2019). Budgetary policy of the emerging countries in conditions of institutional transformations. Problems and Perspectives in Management, 17(4), 252-261. doi:10.21511/ppm.17(4).2019.21

Dave, F. (2020). Municipal finance analysis: The case study of Gujarat (India). Public and Municipal Finance, 9(1), $70-87$. https://doi.org/10.21511/pmf.09(1).2020.07

Dekhtyar, N., Valaskova, K., Deyneka, O., \& Pihul, N. (2020). Assessment of the level of local budget financial decentralization: Case of Ukraine. Public and Municipal Finance,9(1), 34-47. https://doi.org/10.21511/pmf.09(1).2020.04

Dincecco, M. (2009). Fiscal centralization, limited government, and public revenues in Europe. Journal of Economic History, 69(1), 48-103. https://doi.org/10.1017/S0022050709000345

Fairfield, T. (2015). Private wealth and public revenue in Latin America. Business Power and Tax Politics, 1-345. https://doi.org/10.1017/CBO9781316104767

Frolov, S., Bogacki, S., Shukairi, F., \& Bukhtiarova, A. (2021). Evaluation of state budget structural changes based on the coefficient method. Investment Management and Financial Innovations, 18(1), 55-64. https://doi.org/10.21511/imfi.18(1).2021.05

Khalil, R. \& Pandow, B. A. (2020). Influence of fiscal policy on GDP: an empirical study of GCC countries. Investment Management and Financial Innovations, 17(3), 319-331. doi:10.21511/imfi.17(3).2020.24

Kollias, C., \& Paleologou, S. (2006). Fiscal policy in the European union: Tax and spend, spend and tax, fiscal synchronisation or institutional separation? Journal of Economic Studies, 33 (2), 108-120. https://doi.org/10.1108/01443580610666064

Krasnov, A., Okanova, A., Yeraliyeva, Y., Kozhakhmetova, M., Karshalova, A., \& Aitkazina, M. (2020). Development of the financial policy of the Eurasian Economic Union countries: Tax harmonization. Entrepreneurship and Sustainability Issues, 8(1), 138-149. https://doi.org/10.9770/jesi.2020.8.1(9)

Lysiak, L., Kachula, S., Hrabchuk, O., Filipova, M. \& Kushnir, A. (2020). Assessment of financial sustainability of the local budgets: case of Ukraine. Public and Municipal Finance, 9(1), 48-59. doi:10.21511/pmf.09(1).2020.05 
Melnyk, L., Sineviciene, L., Lyulyov, O., Pimonenko, T., \& Dehtyarova, I. (2018). Fiscal decentralization and macroeconomic stability: the experience of Ukraine's economy. Problems and Perspectives in Management, 16(1), 105-114. https://doi.org/10.21511/ppm.16(1).2018.10

Okoye, L. U., Omankhanlen, A. E., Okorie, U. E., Okoh, J. I., \& Ahmed, A. (2019). Persistence of fiscal deficits in Nigeria: examining the issues. Investment Management and Financial Innovations, 16(4), 98-109. https://doi.org/10.21511/imfi.16(4).2019.09

Omari, R. A., \& Khersiat, O. M. (2020). Impact of the application of national integrity standards on the disclosure in the country's general budget (The Jordanian Public Sector). Journal of Legal, Ethical and Regulatory Issues, 23(5), 1-10. Retrieved from www.scopus.com

Pommerehne, W. W., \& Schneider, F. (1978). Fiscal illusion, political institutions, and local public spending. Kyklos, 31(3), 381-408. https://doi.org/10.1111/j.1467-6435.1978.tb00648.x

Romenska, K., Chentsov, V., Rozhko, O., \& Uspalenko, V. (2020). Budget planning with the development of the budget process in Ukraine. Problems and Perspectives in Management, 18(2), 246-260. https://doi.org/10.21511/ppm.18(2).2020.21

Schwarz, R. (2008). The political economy of state-formation in the Arab middle east: Rentier states, economic reform, and democratization. Review of International Political Economy, 15(4), 599-621. https://doi.org/10.1080/09692290802260662

Serikova, M., Sembiyeva, L., Balginova, K., Alina, G., Shakharova, A., \& Kurmanalina, A. (2020). Tax revenues estimation and forecast for state tax audit. Entrepreneurship and Sustainability Issues, 7(3), 2419-2435. https://doi.org/10.9770/jesi.2020.7.3(64)

Serikova, M., Sembiyeva, L., Mussina, A., Kuchukova, N., \& Nurumov, A. (2018). The institutional model of tax administration and aspects of its development. Investment Management and Financial Innovations, 15(3), 283-293. https://doi.org/10.21511/imfi.15(3).2018.23

Shkolnyk, I., \& Bukhtiarova, A. (2020). Analiz zvedenoho biudzhetu Ukrainy z vykorystanniam funktsii bazhanosti Harrinhtona [Analysis of the consolidated budget of Ukraine based on Harrington's desirability function]. Mizhnarodnyi naukovyi zhurnal "Internauka". Seriia: "Ekonomichni nauky" - International scientific journal «Internauka». Series: «Economic sciences», 9(41), 90-97. https://doi.org/10.25313/2520-2294-2020-9-6281

Shkolnyk, I., Kozmenko, O., Nowacki, R., \& Mershchii, B. (2020). Dependence of the state of public finances on their transparency and the level of corruption in a country. Economics and Sociology, 13(4), 281-296. https://doi.org/10.14254/2071-789X.2020/13-4/18

Shkolnyk, I., Kozmenko, S., Polach, J., \& Wolanin, E. (2020). State financial security: Comprehensive analysis of its impact factors. Journal of International Studies, 13(2), 291-309. https://doi.org/10.14254/2071-8330.2020/13$\underline{2 / 20}$

Shvets, S. (2020). The golden rule of public finance under active monetary stance: endogenous setting for a developing economy. Investment Management and Financial Innovations, 17(2), 216-230. doi:10.21511/imfi.17(2).2020.17

Strilets, V., Prokopenko, O., \& Orlov, V. (2020). Impact of Covid-19 on the budget security of the national economy: a forecast for Ukraine. Public and Municipal Finance, 9(1), 25-33. https://doi.org/10.21511/pmf.09(1).2020.03

Turyanskyy, Y., Svydruk, I., Sydorchuk, O., Mitsenko, N., \& Klepanchuk, O. (2020). Management priorities of tax reform in Ukraine: implementation of international experience. Investment Management and Financial Innovations, 17(2), 320-333. https://doi.org/10.21511/imfi.17(2).2020.25

Usher, D. (1986). Tax evasion and the marginal cost of public funds. Economic Inquiry, 24(4), 563-586. https://doi.org/10.1111/j.1465-7295.1986.tb01834.x

Vyhovska, N., Polchanov, A., Aldiwani, K., \& Shukairi, F. (2019). The methodological approaches development to assess the creation and use of the financial capacity of the state. Public and Municipal Finance, 8(1), 28-43. https://doi.org/10.21511/pmf.08(1).2019.03 


\section{APPENDIX A}

Symbols of indicators used to build an economic and mathematical optimization model in terms of state revenues

\begin{tabular}{|c|c|}
\hline $\begin{array}{c}\text { Indicator } \\
\text { symbol }\end{array}$ & Indicator \\
\hline $\mathrm{Y}$ & Integral coefficient of structural changes in GDP by type of activity \\
\hline \multicolumn{2}{|r|}{ Share in GDP of budget revenues from: } \\
\hline $\mathrm{Z}_{1}$ & taxes on income, profit and increase in market value \\
\hline $\mathrm{Z}_{2}$ & fees and charges for the special use of natural resources \\
\hline $\mathrm{Z}_{3}$ & internal taxes on goods and services \\
\hline $\mathrm{Z}_{4}$ & taxes on international trade and foreign transactions \\
\hline $\mathrm{Z}_{5}$ & rent, fees for fuel and energy resources \\
\hline $\mathrm{Z}_{6}$ & other taxes \\
\hline $\mathrm{Z}_{7}$ & property and business activities \\
\hline $\mathrm{Z}_{8}$ & other non-tax revenues \\
\hline $\mathrm{Z}_{9}$ & capital transactions \\
\hline $\mathrm{Z}_{10}$ & trust funds \\
\hline $\mathrm{z}_{11}$ & official transfers \\
\hline
\end{tabular}




\section{APPENDIX B}

Results of calculating the coefficients of structural changes in GDP

\begin{tabular}{|c|c|c|c|c|}
\hline Period & $\begin{array}{c}\text { Linear coefficient of } \\
\text { absolute structural } \\
\text { changes }\end{array}$ & $\begin{array}{c}\text { Quadratic } \\
\text { coefficient of } \\
\text { absolute structural } \\
\text { changes }\end{array}$ & $\begin{array}{c}\text { Quadratic } \\
\text { coefficient of } \\
\text { relative structural } \\
\text { changes } \\
\end{array}$ & $\begin{array}{c}\text { Integral coefficient } \\
\text { of structural } \\
\text { changes }\end{array}$ \\
\hline 2 qr. 2010 & 0.005553999 & 0.008212413 & 0.357970801 & 0.096090871 \\
\hline 3 qr. 2010 & 0.010611116 & 0.025111372 & 1.094579324 & 0.281252457 \\
\hline 4 qr. 2010 & 0.006554429 & 0.017901257 & 0.780297711 & 0.205296733 \\
\hline 1 qr. 2011 & 0.007960894 & 0.012232087 & 0.533184297 & 0.147562197 \\
\hline 2 qr. 2011 & 0.004832849 & 0.006670079 & 0.290742018 & 0.079427139 \\
\hline 3 qr. 2011 & 0.012337202 & 0.028134821 & 1.226368428 & 0.322984248 \\
\hline 4 qr. 2011 & 0.007733020 & 0.017140299 & 0.747128313 & 0.197452819 \\
\hline 1 qr. 2012 & 0.009139813 & 0.015737328 & 0.685974203 & 0.188514980 \\
\hline 2 qr. 2012 & 0.004070256 & 0.005728571 & 0.249702616 & 0.069243635 \\
\hline 3 qr. 2012 & 0.009364435 & 0.023576917 & 1.027693965 & 0.275867995 \\
\hline 4 qr. 2012 & 0.005142246 & 0.012146965 & 0.529473908 & 0.142488180 \\
\hline 1 qr. 2013 & 0.007823702 & 0.014540106 & 0.633788515 & 0.176307186 \\
\hline 2 qr. 2013 & 0.003998543 & 0.006220284 & 0.271135913 & 0.075226608 \\
\hline 3 qr. 2013 & 0.008404497 & 0.020352359 & 0.887138783 & 0.238735990 \\
\hline 4 qr. 2013 & 0.002378173 & 0.004250614 & 0.185279984 & 0.049415946 \\
\hline 1 qr. 2014 & 0.008957123 & 0.020559500 & 0.896167826 & 0.243697746 \\
\hline 2 qr. 2014 & 0.005117501 & 0.007712538 & 0.336181720 & 0.091461509 \\
\hline 3 qr. 2014 & 0.012176886 & 0.030781173 & 1.341720238 & 0.343940263 \\
\hline 4 qr. 2014 & 0.005797073 & 0.014337262 & 0.624946774 & 0.160331587 \\
\hline 1 qr. 2015 & 0.008968088 & 0.018411773 & 0.802550598 & 0.224838979 \\
\hline 2 qr. 2015 & 0.005670751 & 0.008704177 & 0.379406286 & 0.107378543 \\
\hline 3 qr. 2015 & 0.014580443 & 0.035102774 & 1.530094452 & 0.391211342 \\
\hline 4 qr. 2015 & 0.007152095 & 0.015837836 & 0.690355277 & 0.173215156 \\
\hline 1 qr. 2016 & 0.010336627 & 0.023632055 & 1.030097402 & 0.282992374 \\
\hline 2 qr. 2016 & 0.003604886 & 0.005042939 & 0.219816596 & 0.062711736 \\
\hline 3 qr. 2016 & 0.012886343 & 0.033346021 & 1.453519340 & 0.379954900 \\
\hline 4 qr. 2016 & 0.005422643 & 0.011599704 & 0.505619390 & 0.127921582 \\
\hline 1 qr. 2017 & 0.011173508 & 0.026490806 & 1.154707449 & 0.319757087 \\
\hline 2 qr. 2017 & 0.003369636 & 0.005566008 & 0.242616650 & 0.069134403 \\
\hline 3 qr. 2017 & 0.012970840 & 0.031509661 & 1.373474279 & 0.362594600 \\
\hline 4 qr. 2017 & 0.006165593 & 0.012912970 & 0.562863324 & 0.146669972 \\
\hline 1 qr. 2018 & 0.011257226 & 0.022183182 & 0.966942470 & 0.269029484 \\
\hline 2 qr. 2018 & 0.003392261 & 0.005114904 & 0.222953508 & 0.063600947 \\
\hline 3 qr. 2018 & 0.011446916 & 0.027727282 & 1.208604204 & 0.327035497 \\
\hline 4 qr. 2018 & 0.003832989 & 0.007749447 & 0.337790554 & 0.089963818 \\
\hline 1 qr. 2019 & 0.011786960 & 0.024671766 & 1.075417326 & 0.301324133 \\
\hline 2 qr. 2019 & 0.003122261 & 0.004782033 & 0.208443972 & 0.059432810 \\
\hline 3 qr. 2019 & 0.010633368 & 0.025438733 & 1.108848675 & 0.304109842 \\
\hline 4 qr. 2019 & 0.004474401 & 0.008386810 & 0.365572554 & 0.099726210 \\
\hline
\end{tabular}

